\title{
PERANCANGAN APLIKASI PESAN TANDING FUTSAL DENGAN METODE WATERFALL
}

\section{DESIGN OF FUTSAL MATCH MESSAGE APPLICATION WITH WATERFALL METHOD}

\author{
Sumardiono*, Mus Mulyadi Maulana \\ * Manajemen Informatika, AMIK Purnama Niaga Indramayu, Indramayu-Indonesia \\ *Jalur Lohbener-Cirebon No.168, Karanganyar, Kec. Indramayu, Kabupaten Indramayu, Jawa Barat- \\ Indonesia 45213
}

\begin{tabular}{l} 
Informasi Artikel \\
\hline Article History: \\
Submission: $20 / 05 / 2021$ \\
Revised: $01 / 06 / 2021$ \\
Accepted: $15 / 06 / 2021$ \\
Kata Kunci: \\
Metode FCFS; SDLC methodologies; \\
Metode Waterfall \\
Keywords: \\
FCFS method; SDLC methodologies; \\
Waterfall method.
\end{tabular}

* Korespondensi:

Sumardiono sumardiono@amikpurnamaniaga.ac.id

\begin{abstract}
Abstrak
Futsal merupakan salah satu jenis olahraga beregu atau berkelompok dan masuk cabang atletik dengan jumlah pemain dalam satu kelompok 5 pemain. Dengan banyaknya minat masyarakat akan olahraga sepak bola (futsal), lebih dari 30 club/team futsal se kecamatan Sindang. Sebanyak 60\% dari jumlah itu menjadi pelanggan tetap di Vianos Futsal. Dalam satu minggu lebih dari 20 team/club menyewa lapangan. Jadi, untuk memudahkan penjadwalan dan pengaturan dalam penggunaan lapangan futsal (booking sarana), penulis merancang sistem pengaturan pinjaman lapangan dengan metode First Come First Serve (FCFS) yaitu pertama daftar, maka pertama dilayani. Dalam perancangan sistem informasi pesan tanding futsal, penulis melakukan beberapa metode pengembangan sistem yaitu dengan menggunakan metodologi SDLC. SDLC has a similar set of four fundamental phases: planning, analysis, design, and implementation. Dari hasil penelitian ini diperoleh rancang bangun aplikasi berupa aplikasi login dan register akun, aplikasi penyewaan, aplikasi laporan pemesanan, dan aplikasi atur jadwal. Tentunya masih terdapat kekurangan dalam sistem ini sehingga perlu adanya penelitian berikutnya untuk pengembangan sistem yang lebih baik.
\end{abstract}

Abstract
Futsal is a type of team or group sport and is included in athletics
with the number of players in a group of five players. With so much
public interest in soccer (futsal), more than 30 futsal clubs/teams in
the Sindang district. As many as $60 \%$ of that number became regular
customers at Vianos Futsal. In one week, more than 20 teams/clubs
rent the field. So, to facilitate scheduling and regulation in the use of
the futsal field (booking facilities), the authors designed a field loan
arrangement system using the First Come First Serve (FCFS) method,
namely first register, then first served. In designing the futsal match
message information system, the author uses several methods of
system development, namely by using the SDLC methodology. SDLC
has a similar set of four fundamental phases: planning, analysis,
design, and implementation. From the results of this study, it was
obtained that the application design was in the form of an account
login and register application, a rental application, a booking report
application, and a schedule application. Of course, there are still

Abstract
Futsal is a type of team or group sport and is included in athletics
with the number of players in a group of five players. With so much
public interest in soccer (futsal), more than 30 futsal clubs/teams in
the Sindang district. As many as $60 \%$ of that number became regular
customers at Vianos Futsal. In one week, more than 20 teams/clubs
rent the field. So, to facilitate scheduling and regulation in the use of
the futsal field (booking facilities), the authors designed a field loan
arrangement system using the First Come First Serve (FCFS) method,
namely first register, then first served. In designing the futsal match
message information system, the author uses several methods of
system development, namely by using the SDLC methodology. SDLC
has a similar set of four fundamental phases: planning, analysis,
design, and implementation. From the results of this study, it was
obtained that the application design was in the form of an account
login and register application, a rental application, a booking report
application, and a schedule application. of course, there are still Infotech: Jurnal Informatika \& Teknologi is licensed under a Creative Commons Attribution-NonCommercial 4.0 International License. p ISSN 2722-9378 | e ISSN 2722-9386 


\section{PENDAHULUAN.}

Perkembangan perdagangan modern sangat dipengaruhi dengan kemajuan dan kemudahan dalam sistem informasi[2][3]. Akan tetapi, bisnis bukan hanya dalam hal perdagangan saja, bahkan lingkupnya luas, seperti halnya penyewaan jasa lapangan futsal. Futsal merupakan salah satu jenis olahraga beregu atau berkelompok dan masuk cabang atletik yang beranggotakan 5 orang dalam satu kelompok. Futsal merupakan jenis permainan olahraga sepakbola yang telah mengalami evolusi terkait dengan permainan dan peraturan, sehingga peminatnya semakin banyak[4]. Futsal tahun-tahun ini, sering dijadikan ajang pertandingan yang cukup dibilang masif, seperti yang disiarkan oleh televisi nasional (MNCTV).

Perkembangan sekarang, masyarakat daerah banyak melakukan olahraga seperti futsal terutama kalangan pelajar dan mahasiswa, perkantoran, bahkan masyarakat umum. Sehingga, oleh pemilik penyewa lapangan tanding futsal sering kebanjiran penyewa/pengguna, dan akhirnya catatan secara manual sering terjadi kesalahan-kesalahan atau rusak. Lebih dari 30 team/club futsal di Kecamatan Sindang dan 60\% menjadi pelanggan di Vianos Futsal. Dalam satu minggu lebih dari 20 team/club bertanding di lapangan Vianos Futsal. Melihat padatnya penggunaan lapangan yang dilakukan secara home service[5], sehingga terlihat bahwa terjadinya permasalahan-permasalahan yang terjadi.

Dengan adanya permasalahan tersebut, maka perlu dirancang sistem pengaturan sewa lapangan secara prinsip FCFS, yaitu proses dimana setiap antrian[6] akan dilayani sebagaimana awal dari proses penyewaan. Dari sistem tersebut diperoleh untuk mengontrol yang bersifat manajerial[7] sehingga permintaan pengguna dapat ditangani dengan baik. Pengembangan dan perancangan sistem dengan menggunakan metode waterfall, sebagaimana tahap-tahap pengembangan sistem ini[8]. Sistem ini adalah sistem penyewaan lapangan yang berkaitan dengan jasa sewa barang dan tempat dengan diberikan waktu (babak) dalam permainan tanding futsal. Vianos futsal merupakan nama dari sarana-prasarana penyewaan lapangan futsal, yang bertempat di Kecamatan Sindang, Kabupaten Indramayu.

\section{METODE}

Penelitian ini dilakukan pada Vianos Futsal, dan merupakan jasa penyewaan lapangan siap tanding futsal dengan sarana berupa lapangan futsal dan prasarana berupa bola dan perlengkapan pemain (baju dan perlengkapan permainan).

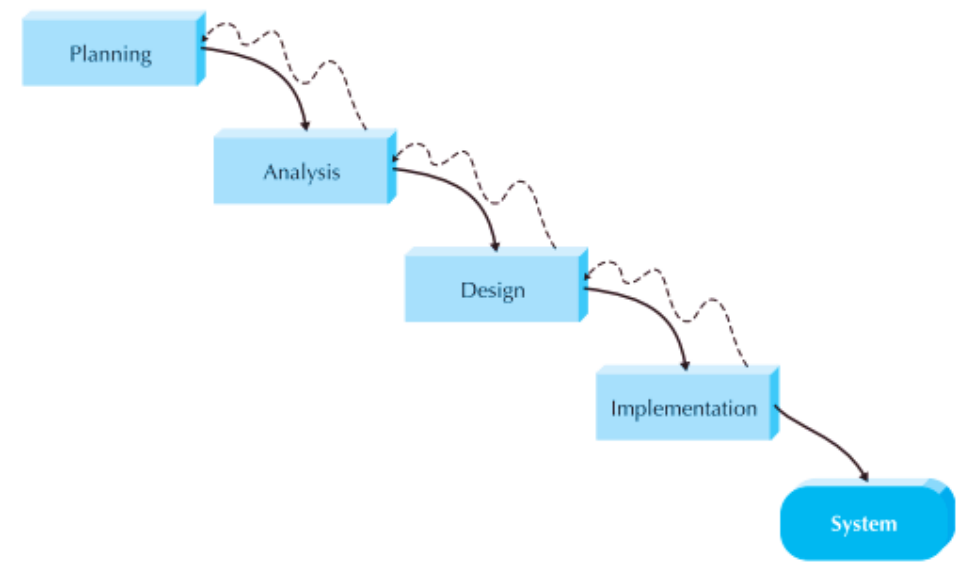




\section{Gambar 1. Alur penelitian}

Sebagaimana dijelaskan para ahli[1] bahwa waterfall method terdiri dari tahapan yaitu analisis, desain, implementasi, dan sistem. Pengembangan sistem ini menggunakan metode Waterfall dengan prinsip FCFS.

\section{HASIL DAN PEMBAHASAN}

Sebelum ke tahap perencanaan, terdapat beberapa temuan data yang mana akan diproses sebagai bahan perencanaan dan analis. Temuan data tersebut menggunakan teknik pengambilan data, seperti observasi dan wawancara. Dalam melakukan wawancara dengan pemilik dan kasir, penulis menggunakan metode terstruktur, sehingga data yang diperoleh sesuai dengan konsep pertanyaan. Data tersebut diantaranya adalah buku catatan yang rusak, sehingga dalam laporan dari kasir ke pemilik tidak jelas; tidak jelasnya pengguna/penyewa lapangan, sehingga bilamana ada event-event tanding oleh pemilik tidak diundang; pemesanan yang tidak efektif, sehingga tidak tercatat dan memberikan informasi peminjaman yang jelas; jadwal yang saling tumpang tindih yang menyebabkan diambilnya pesanan orang lain; dan laporan kas. Dari hasil data di atas, maka diperoleh analisa oleh peneliti yaitu perlunya dikembangkan (di program) [9] dalam bentuk sistem informasi.

a) Aplikasi registrasi: menjelaskan terkait dengan fitur pendaftar akun, dengan menuliskan data yang digunakan dalam fitur ini, seperti nama lengkap, email, dst.

b) Aplikasi login: merupakan fitur masuknya akun yang telah terdaftar di aplikasi registrasi.

c) Aplikasi pemesanan: merupakan sebuah fitur pemesanan yang terdapat beberapa atribut lapangan, tanggal sewa, pilihan sewa.

d) Aplikasi atur jadwal: merupakan fitur lanjutan dalam aplikasi pemesanan dengan cara memilih salah satu pilihan sewa sehingga akan tampil fitur atur jadwal.

e) Aplikasi laporan pemesanan: merupakan fitur aplikasi setelah user menekan salah satu tombol tunai atau transfer (pembayaran).

\subsection{Perancangan}

A. Use case diagram 


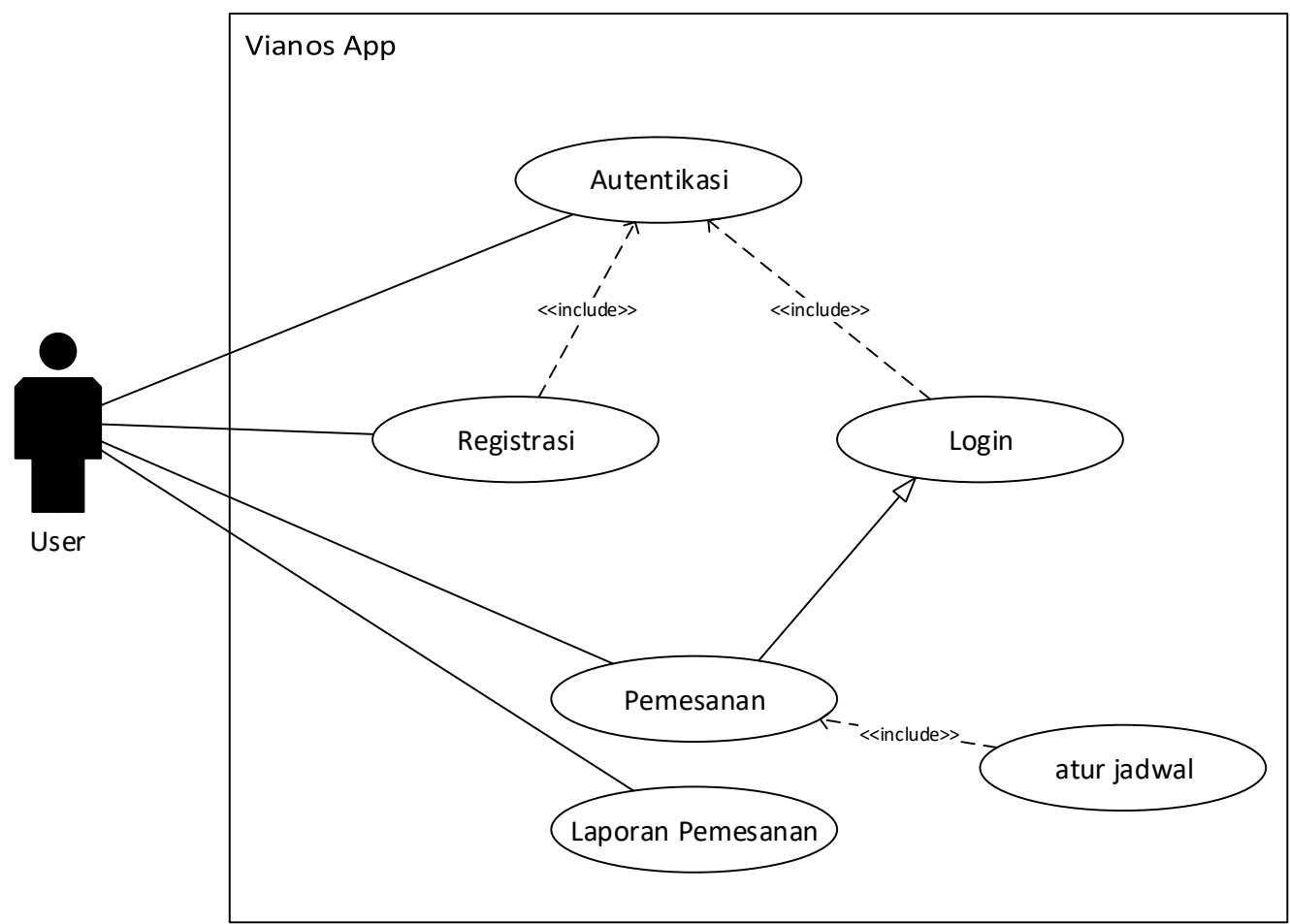

Gambar 3. Diagram use case vianos App

Dalam perancangan, peneliti menggunakan metode Unified Modelling Language (UML) atau Object-Oriented Analysis Diagram (OOAD). Unified Modeling Language (UML) merupakan standar industri yang digunakan untuk pemodelan sistem yang menggunakan pendekatan OOAD [10]. Perancangan sistem ini menggunakan hanya model Use Case Diagram (UCD), Class Diagram (CD), dan Activity Diagram (AD). Dengan menggunakan OOAD, peneliti merancang dengan bentuk object yang ada pada aplikasi tersebut. Dilihat dari pertama (register akun) sampai dengan menampilkan pemesanan dan laporan pemesanan. Untuk Structured Diagram disampaikan dengan bentuk class diagram, untuk Behavior Diagram disampaikan dengan bentuk Use Case Diagram dan Activity Diagram.

B. Class diagram

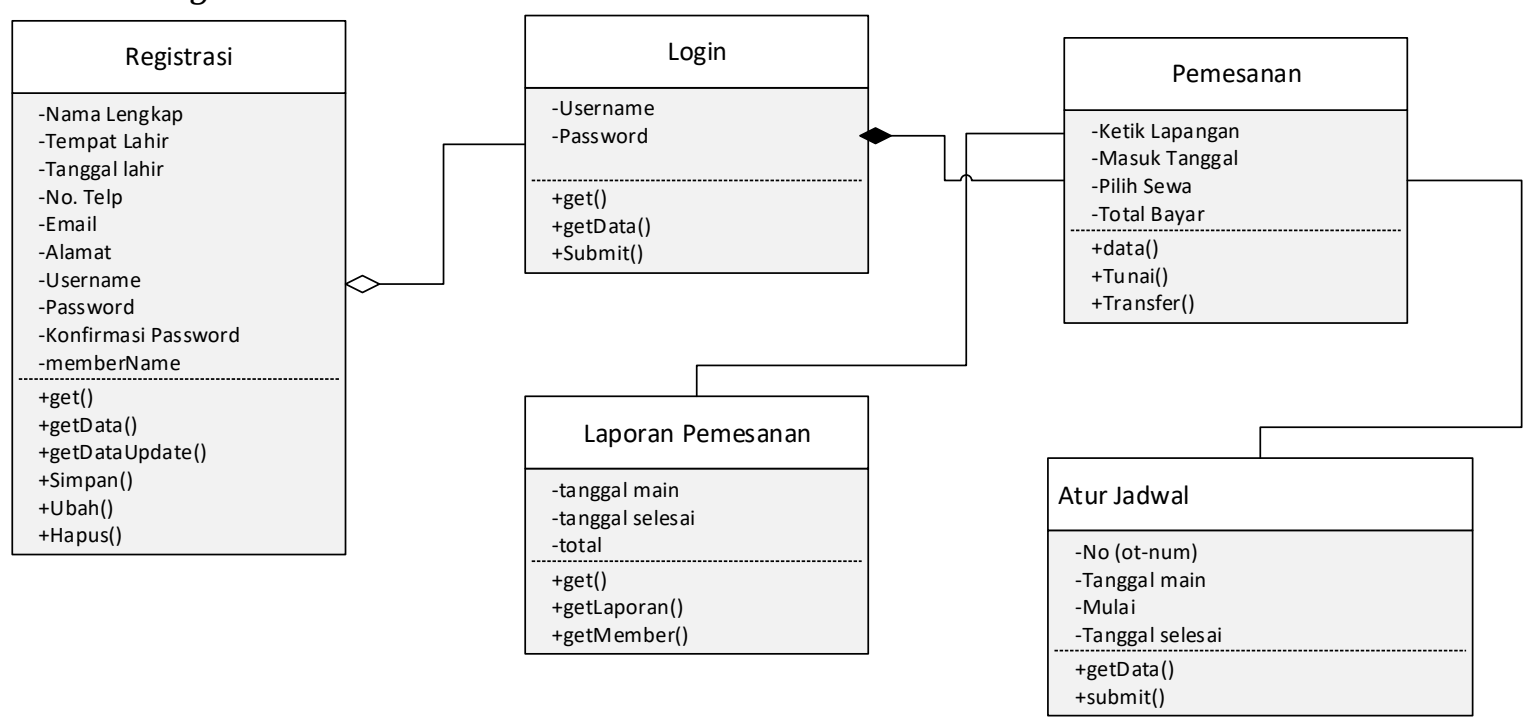

Gambar 4. Diagram class vianos App 


\section{Activity diagram}
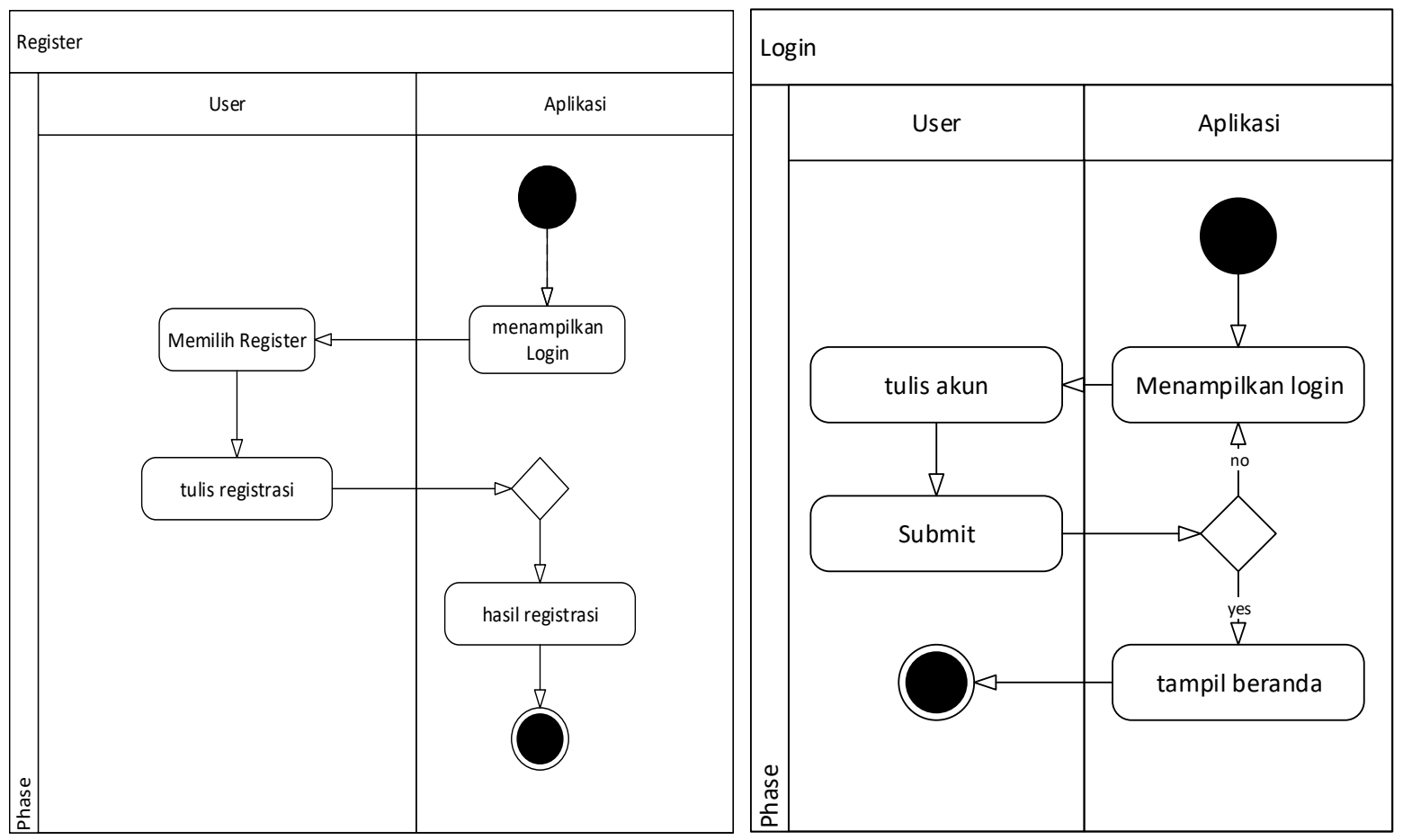

Gambar 5. Diagram aktivitas registrasi dan login

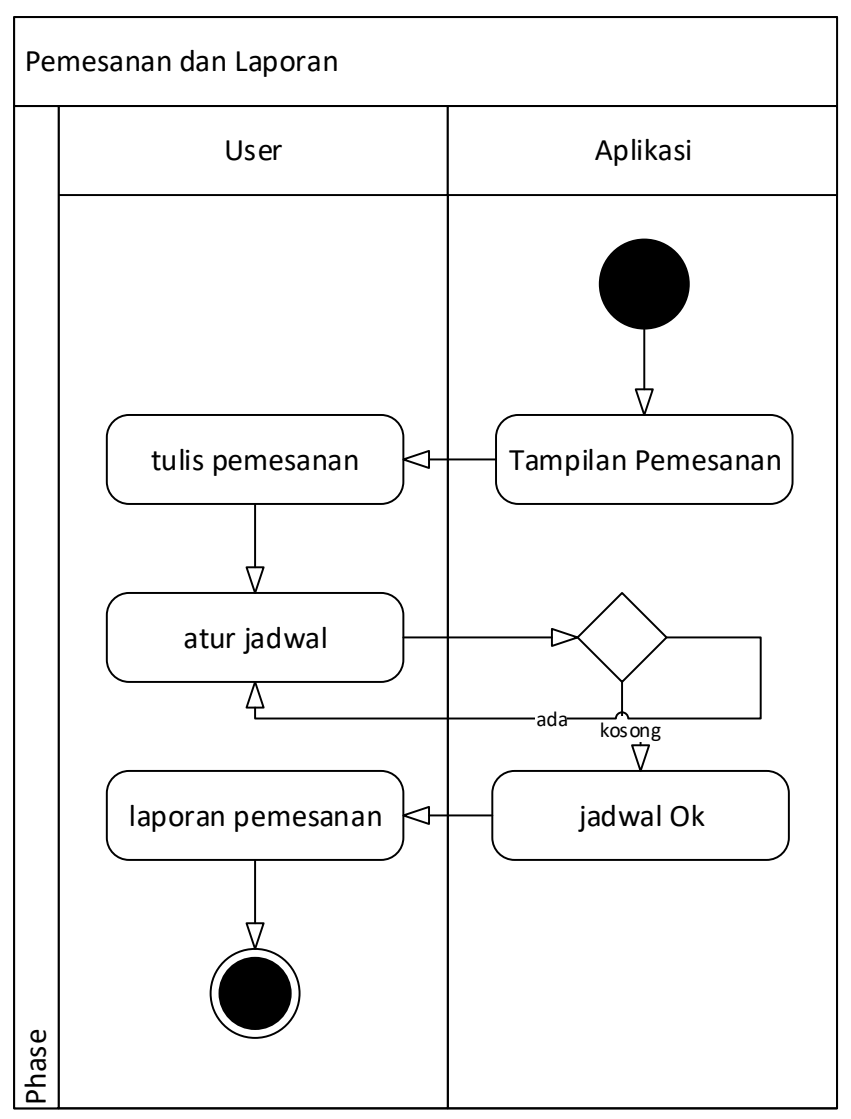

Gambar 6. Diagram aktivitas pemesanan dan laporan pemesanan

\subsection{Implementasi}


Pada tahap implementasi yang akan dibahas adalah berupa tampilan user interface design, yang mana hasil dari perancangan di atas dalam bentuk aplikasi yang nantinya akan diterapkan pada pengguna. Adapun tampilan-tampilan tersebut terdiri dari tampilan login (awal), tampilan registrasi (pendaftaran akun), tampilan pemesanan, tampilan laporan pemesanan yang dijelaskan pada gambar $7 \& 8$.

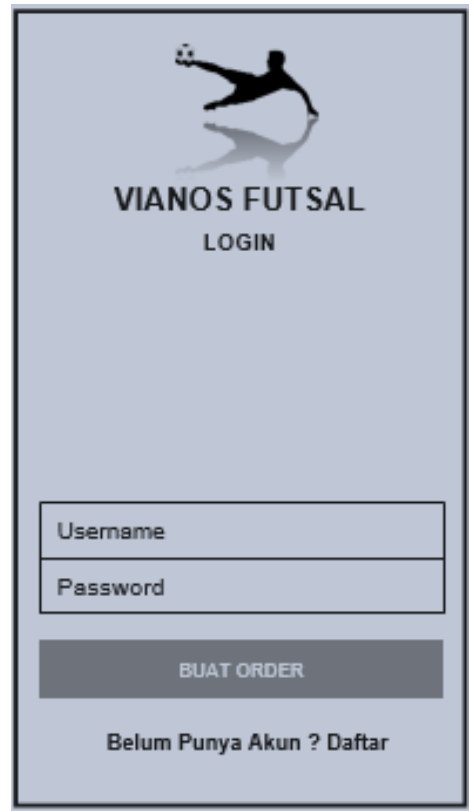

\section{Gambar 7. Username}

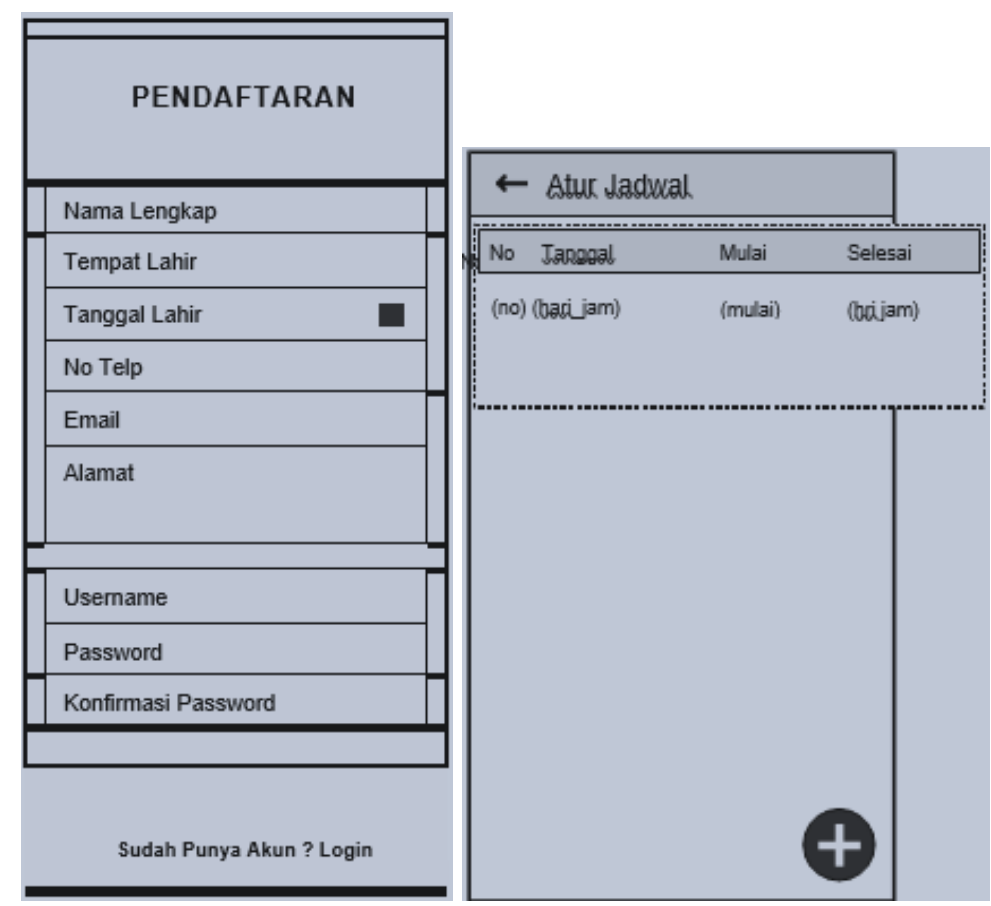

Gambar 8. Tampilan login, registrasi, atur jadwal 


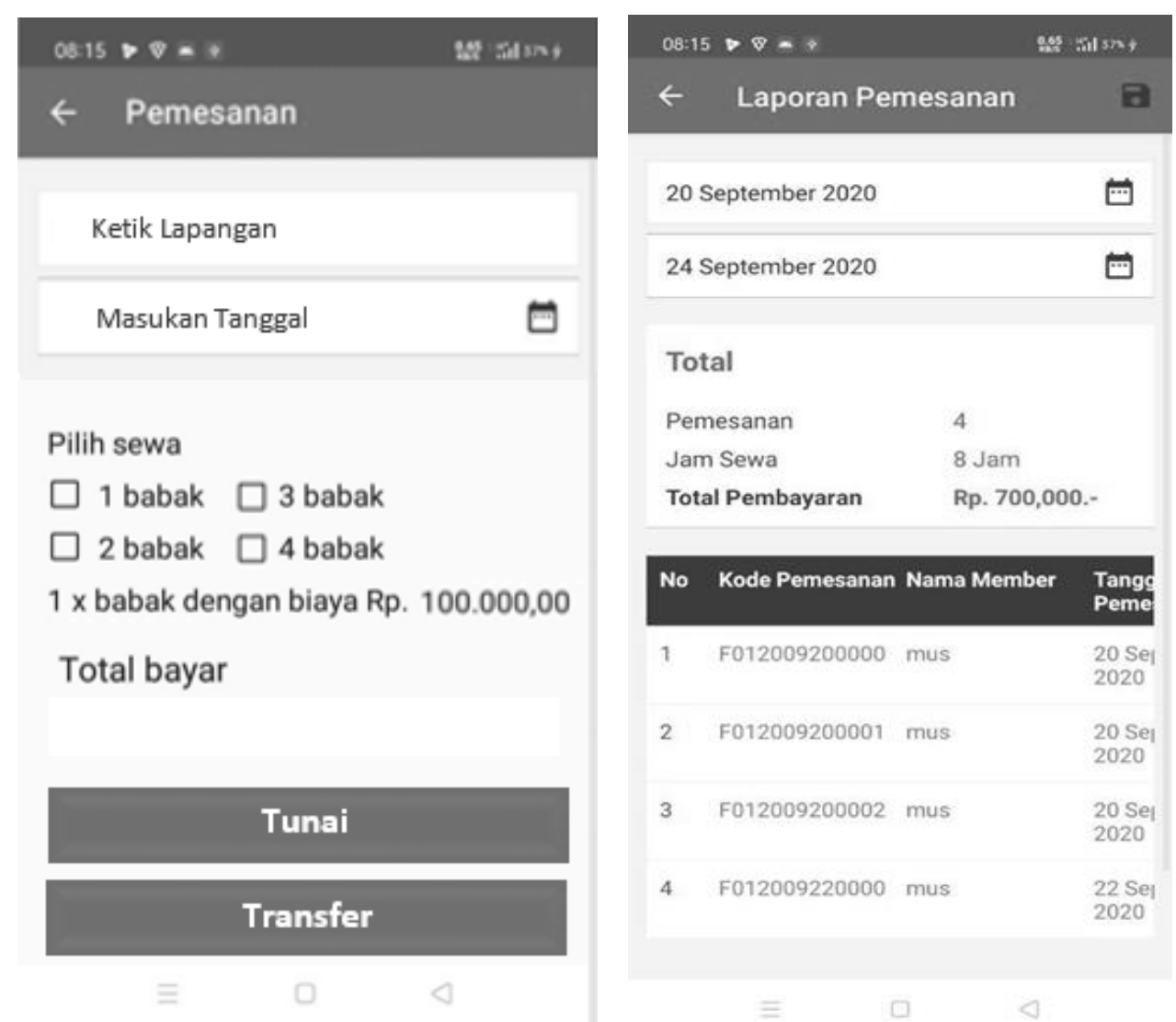

\subsection{Sistem}

Gambar 9. Tampilan pemesanan dan laporan pemesanan

Pada tahapan ini peneliti melakukan pengujian aplikasi [11], bahwa waterfall method di tahap ini sebagai tahap evaluasi. Hasil uji sistem tersebut dengan menggunakan Blackbox testing[12].

Tabel 1. Hasil uji program

\begin{tabular}{llll}
\hline \multicolumn{1}{c}{ Data Sampel } & Hasil Perkiraan & Hasil Real & Kesimpulan \\
\hline Registrasi & Valid & Valid & Success \\
Login & Valid & Valid & Success \\
Atur jadwal & Invalid & Valid & Success \\
Pemesanan & Invalid & Valid & Success \\
Laporan & & & \\
Pemesanan & Invalid & Valid & Success \\
\hline
\end{tabular}

Sistem ini dibangun dengan spesifikasi.
a. Memori utama minimal (RAM) 4GB / 8GB diutamakan;
b. Prosesor Intel Core i5-3470 CPU @ 3.20 Ghz
c. NVIDIA GeForce $2103.004 \mathrm{Mb} 64$ bit
d. Wireless LAN Network (Tethering/Wifi)
e. Modem/Internet Connection
f. Smartphone Android (Min Sdkv 22 / v5.1 Lollipop)

\section{SIMPULAN}


Vianos Futsal merupakan jasa penyewaan sarana-prasarana lapangan tanding futsal di Kecamatan Sindang Kabupaten Indramayu. Vianos futsal mengembangkan penyewaan dalam bentuk sistem informasi yang berbasiskan Android. Pengembangan tersebut bertujuan untuk memudahkan pelanggan/customers dalam melakukan penyewaan serta memperbaiki sistem pendaftaran yang sebelumnya masih menggunakan buku catatan. Vianos Aplikasi merupakan bentuk implementasi suatu sistem dalam hal antrian pemesanan lapangan tanding futsal dengan prinsip pertama datang maka pertama terjadwal, dengan difasilitasi berupa pendaftaran akun, login, pemesanan dan atur jadwal, serta laporan pemesanan. Pengembangan Vianos Aplikasi ini menggunakan metode air terjun (waterfall method), dan masih bersifat sederhana. Akan tetapi, aplikasi ini masih membutuhkan rancangan yang lebih baik sehingga memberikan kualitas pada sistem informasinya, baik secara keamanan sistem, pengujian sistem secara white box serta kualitas perangkat lunak dengan ISO 9126[9].

\section{UCAPAN TERIMA KASIH}

Dalam penyampaian ucapan terima kasih ini disampaikan pada seluruh pihak yang telah berkontribusi dalam penelitian ini.

- Direktur AMIK Purnama Niaga, Indramayu

- Ketua LPPM AMIK Purnama Niaga, Indramayu

- Pengelola Vianos Futsal Indramayu

- Desi Nawang Wulan (Istri tercinta)

\section{DAFTAR PUSTAKA}

[1] A. Dennis, B. H. Wixom, and D. Tegarden, Systems Analysis and Design with UML Version 2.0. John Wiley \& Sons, Inc., 2009.

[2] Sumardiono, "ANALISIS BISNIS DALAM PERENCANAAN STRATEGIS SISTEM INFORMASI PADA PD. INDRASARI," J. Inform., vol. 20, no. 2, pp. 137-143, 2020, doi: http://dx.doi.org/10.30873/ji.v20i2.

[3] Sumardiono, "Lingkungan Eksternal Bisnis Dalam Perencanaan Strategis Sistem Informasi Pada Perusahaan Kerupuk Di Kabupaten Indramayu," BEMAS J. Bermasyarakat, vol. 1, no. 1, pp. 25-32, 2020, doi: 10.37373/bemas.v1i1.39.

[4] Aswadi, N. Amir, and Karimuddin, "Penelitian Tentang Perkembangan Cabang Olahraga Futsal Di Kota Banda Aceh Tahun 2007-2012," J. Ilm. Mhs. Pendidik. Jasmani, Kesehat. dan Rekreasi Fak. Kegur. dan Ilmu Pendidik. Unsyiah, vol. 1, no. 1, pp. 38-44, 2015.

[5] A. Prasetiya, "Rancang Bangun Aplikasi Penjadwalan Home," TRANSFORMATIKA, vol. 18, no. 2, pp. 173-181, 2021.

[6] P. Manesia, N. A. Hasibuan, and I. Saputra, "Perancangan Aplikasi Daftar Menu Restoran Berbasis Android Menggunakan Metode Multilevel Queue," J. Pelita Inform., vol. 8, no. April, pp. 402-407, 2020.

[7] H. Nurdiyanto and H. Meilia, "Sistem Pendukung Keputusan Penentuan Prioritas Pengembangan Industri Kecil Dan Menengah Di Lampung Tengah Menggunakan Analitical Hierarchy Process (Ahp)," Semnasteknomedia Online, vol. 4, no. 1, pp. 3-3-37, 2016, [Online].

Available: https://ojs.amikom.ac.id/index.php/semnasteknomedia/article/view/1163.

[8] G. W. Sasmito, "Penerapan Metode Waterfall Pada Desain Sistem Informasi Geografis Industri Kabupaten Tegal," J. Inform. Pengemb. IT, vol. 2, no. 1, pp. 6-12, 2017.

[9] A. Saputra, A. Imamuddin, and P. Sukamto, "RANCANG BANGUN APLIKASI SISTEM PENJUALAN CASE STUDY: PT. X," INFOTECH, vol. 1, pp. 78-86, 2020, doi: 10.37373/infotech.v1i2.67.

[10] I. A. W. H. N. P. Cindy Retno Dewati, "Analisis dan Perancangan Sistem Informasi 
Pengarsipan Dokumen Dengan Pendekatan Berorientasi Objek (Studi Kasus: Dinas Sekretariat Dewan, Pemerintahan Kota Batu)," J. Pengemb. Teknol. Inf. dan Ilmu Komput., vol. 3, no. 5, pp. 5140-5146, 2019.

[11] Sumardiono, "PERANCANGAN SISTEM PENILAIAN (E-RESULT) PEGAWAI DENGAN MODEL WATERFALL DI UNIVERSITAS XYZ," TEKNOSAINS J. Sains, Teknol. dan Inform., vol. 8, no. 1, pp. 45-53, Jan. 2021, doi: 10.37373/tekno.v8i1.76.

[12] T. S. Jaya, "Pengujian Aplikasi dengan Metode Blackbox Testing Boundary Value Analysis (Studi Kasus: Kantor Digital Politeknik Negeri Lampung)," J. Inform. Pengemb. IT, vol. 3, no. 2, pp. 45-46, 2018, doi: 10.30591/jpit.v3i1.647. 